\title{
Gas exchange rates, plant height, yield components, and productivity of upland rice as affected by plant regulators
}

\author{
Rita de Cássia Félix Alvarez(1), Carlos Alexandre Costa Crusciol(2), Adriano Stephan Nascente ${ }^{(3)}$, \\ João Domingos Rodrigues ${ }^{(4)}$ and Gustavo Habermann ${ }^{(5)}$
}

\begin{abstract}
(1)Universidade Federal do Mato Grosso do Sul, Caixa Postal 112, CEP 79560-000 Chapadão do Sul, MS, Brazil. E-mail: rita.alvarez@ufms.br (2)Universidade Estadual Paulista (Unesp), Faculdade de Ciências Agronômicas, Departamento de Produção e Melhoramento Vegetal, Caixa Postal 237, CEP 18610-307 Botucatu, SP, Brazil. E-mail: crusciol@fca.unesp.br ${ }^{(3)}$ Embrapa Arroz e Feijão, Caixa Postal 179, CEP 75375-000 Santo Antônio de Goiás, GO, Brazil. E-mail: adriano.nascente@embrapa.br (4)Unesp, Instituto de Biociências (IB), Departamento de Botânica, Caixa Postal 510, CEP 18610-307 Botucatu, SP, Brazil. E-mail: mingo@ibb.unesp.br; ${ }^{(5)}$ Unesp, IB, Departamento de Botânica, Avenida 24-A, no1515, Bela Vista, CEP 13506-900 Rio Claro, SP, Brazil, E-mail ghaber@rc.unesp.br
\end{abstract}

\begin{abstract}
The objective of this work was to evaluate gas exchange rates, plant height, yield components, and productivity of upland rice, as affected by type and application time of plant growth regulators. A randomized block design, in a $4 \times 2$ factorial arrangement, with four replicates was used. Treatments consisted of three growth regulators (mepiquat chloride, trinexapac-ethyl, and paclobutrazol), besides a control treatment applied at two different phenological stages: early tillering or panicle primordial differentiation. The experiment was performed under sprinkler-irrigated field conditions. Net $\mathrm{CO}_{2}$ assimilation, stomatal conductance, plant transpiration, and water-use efficiency were measured four times in Primavera upland rice cultivar, between booting and milky grain phenophases. Gas exchange rates were neither influenced by growth regulators nor by application time. There was, however, interaction between these factors on the other variables. Application of trinexapac-ethyl at both tillering and differentiation stages reduced plant height and negatively affected yield components and rice productivity. However, paclobutrazol and mepiquat chloride applied at tillering, reduced plant height without affecting rice yield. Mepiquat chloride acted as a growth stimulator when applied at the differentiation stage, and significantly increased plant height, panicle number, and grain yield of upland rice.

Index terms: Oryza sativa, net photosynthesis, stomatal conductance, transpiration, water-use efficiency.

\section{Taxas de trocas gasosas, altura de planta, componentes de produção e produtividade de arroz de terras altas afetados por reguladores vegetais}

Resumo - O objetivo deste trabalho foi avaliar taxas de trocas gasosas, altura de plantas, componentes de produção e produtividade do arroz de terras altas, influenciados pelo tipo e pela época de aplicação de reguladores de crescimento vegetal. O delineamento experimental foi utilizado em blocos ao acaso, em arranjo fatorial $4 \times 2$, com quatro repetições. Os tratamentos consistiram de três reguladores vegetais (cloreto de mepiquat, trinexapac-etil e paclobutrazol), além de um tratamento controle, aplicados em dois estádios fenológicos: início do perfilhamento ou primórdio da diferenciação da panícula. O experimento foi conduzido em campo com irrigação por aspersão. A assimilação líquida de $\mathrm{CO}_{2}$, a condutância estomática, a transpiração e a eficiência do uso da água foram avaliadas na cultivar de sequeiro Primavera, por quatro vezes, entre os estágios de emborrachamento e de grão leitoso. As trocas gasosas não foram influenciadas nem pelos reguladores, nem pelas épocas de aplicação. Houve interação entre os efeitos dos fatores sobre as demais variáveis. A aplicação de trinexapac-etil, tanto no perfilhamento como na diferenciação, reduziu a altura de plantas e afetou negativamente os componentes de produção e a produtividade do arroz. No entanto, o paclobutrazol e o cloreto de mepiquat, aplicados no estágio de perfilhamento, reduziram a altura das plantas sem afetar a produção. O cloreto de mepiquat atuou como promotor de crescimento quando aplicado no estágio de diferenciação de panículas, e aumentou significativamente a altura das plantas, o número de panículas e a produtividade de grãos.

Termos para indexação: Oryza sativa, fotossíntese líquida, condutância estomática, transpiração, eficiência de uso da água.

\section{Introduction}

Upland rice is cultivated in Asia, Africa, and Americas, and its importance is increasing worldwide, since water availability for irrigation is decreasing, mainly in Asia (Tuong \& Bouman, 2003; Kumar \& Ladha, 2011). In Brazil, rice is grown under lowland (irrigated) and upland (with or without irrigation) 
conditions. However, Brazilian rainfed rice cultivation system has not been performing well, with low-average yields (Crusciol et al., 2012). This is mostly due to uneven rain distribution, poor fertilization and inadequate liming (Santos et al., 2006).

Upland rice cultivation under irrigation has prompted the use of high-level technological practices, with a consequent increase in crop yield (Arf et al., 2001). In this sense, the use of sprinkler irrigation in upland rice crops is an important option to stabilize and increase grain yield, and also to improve grain quality (Crusciol et al., 2008). Therefore, proper water supply may allow high yield of upland rice (Guimarães et al., 2011). In addition, the use of central pivots is becoming frequent to irrigate upland rice plantations in the state of São Paulo, Brazil, in rotational systems with beans, corn, wheat, potato or cotton (Arf et al., 2001, 2012; Crusciol et al., 2012).

In order to yield, any crop depends on its photosynthetic capacity, and on how plants allocate carbohydrates for growth and development (Ntanos \& Koutroubas, 2002; Falqueto et al., 2009). Respiration rates are normally influenced by plant development stage, air temperature, nitrogen leaf concentration, and soil water availability (Lee et al., 2005; Souza et al., 2008; Habermann et al., 2011). The balance between respiration and photosynthesis has a direct influence on plant yield. However, there is not much data available regarding the wide spectrum of possibilities that affect carbon balance in tropical plants (Wright et al., 2005; Souza et al., 2008; Fagan et al., 2010). Additionally, in major crops like cotton, sugarcane, wheat and soybeans, plant growth regulators (PGR) have been most commonly used to reduce plant height and to provide greater plant uniformity (Nascimento et al., 2009; Espindula et al., 2011; Leite et al., 2011). Some of these regulators are biosynthesis inhibitors of gibberellins, a plant hormone associated with stem elongation (Buzetti et al., 2006; Nascimento et al., 2009). In rice, these PGR are used to reduce plant height and, as a consequence, to reduce plant lodging.

Nevertheless, for upland rice cultivation, there is a lack of information regarding the relationship between PGR and physiological aspects involved in plant production, such as carbon gain and gas exchange. Typical studies have only evaluated the effects of PGR on plant height and crop yield (Nascimento et al., 2009), without analyzing photosynthetic relationships. In this sense, mepiquat chloride (PIX), a gibberellins' biosynthesis inhibitor, has been described to reduce photosynthetic capacity, leaf area, and Ribulose-1,5-carboxylase/oxygenase (Rubisco) activity in cotton plants (Reddy et al., 1996). Nevertheless, soybean plants treated with strobilurin had photosynthesis rates and yield increased (Fagan et al., 2010). Proper use of the correct type of PGR and its optimum application time could help reduce plant height without gas exchange loss, which would possibly have a direct effect on grain yield.

Therefore, we tested the hypothesis that gas exchange rates can be affected by the use of different types of PGR, applied at different phenological phases of upland rice plants.

The objective of this work was to evaluate gas exchange rates, plant height, yield components, and productivity of upland rice, as affected by type and application time of plant growth regulators.

\section{Materials and Methods}

The experiment was performed in the rainy season (January-June, 2004) in Botucatu, SP, Brazil $\left(48^{\circ} 23^{\prime} \mathrm{W}, 22^{\circ} 51^{\prime} \mathrm{S}\right.$, at $765 \mathrm{~m}$ altitude), where climate can be described as Cwa, according to the Köppen's classification system. Average maximum and minimum temperatures of 26.5 and $17^{\circ} \mathrm{C}$ were respectively observed, as well as an annual rainfall of 1,455 $\mathrm{mm}$ was measured in the year of the field experiment. The soil type was an Ultisoil (international taxonomy).

Soil fertility was determined $(0-20 \mathrm{~cm})$ according to Raij et al. (2001), and the results were: $\mathrm{pH}\left(\mathrm{CaCl}_{2}\right)$, 5.5; organic matter, $21 \mathrm{~g} \mathrm{~kg}^{-1}$; $\mathrm{P}$ (resin), $35 \mathrm{mg} \mathrm{dm}^{-3}$; exchangeable $\mathrm{K}, \mathrm{Ca}, \mathrm{Mg}$, and potential acidity $(\mathrm{H}+\mathrm{Al})$ as $2.5,38,17$, and $43 \mathrm{mmol}_{\mathrm{c}} \mathrm{dm}^{-3}$, respectively; and base saturation, $57 \%$. Nutrient management was based on the common practices prescribed for the upland rice cultivation system (Raij et al., 1996). Nitrogen was used as urea $\left(20 \mathrm{~kg} \mathrm{ha}^{-1} \mathrm{~N}\right), \mathrm{P}$ as simple superphosphate (120 kg ha-1 $\mathrm{P}_{2} \mathrm{O}_{5}$ ), and $\mathrm{K}$ as potassium chloride (60 $\mathrm{kg} \mathrm{ha}^{-1} \mathrm{~K}_{2} \mathrm{O}$ ), which were added into the sowing furrows.

Seeds were sown in the first week of December, using $0.40 \mathrm{~m}$ between rows and 80 seeds per meter. The rice cultivar Primavera, which has an early season length, great height, and low resistance to lodging, was used. Primavera also has long and thin grains, which are references of quality for upland rice. Therefore, this 
is one of the most important cultivars in this cropping system (Santos et al., 2006; Arf et al., 2012).

A randomized block design, in a $4 \times 2$ factorial arrangement, was used with four replicates. We studied the effect of PGR - $100 \mathrm{~g} \mathrm{ha}^{-1}$ a.i. mepiquat chloride (MC); $50 \mathrm{~g} \mathrm{ha}^{-1}$ a.i. paclobutrazol (PBZ); $100 \mathrm{~g} \mathrm{ha}^{-1}$ a.i. trinexapac-ethyl (TXE) - and of plant phenological stages at PGR application - early tillering phase and panicle primordium differentiation phase - on gas exchange rates, plant height, yield components, and productivity of upland rice. A control treatment, with no PGR application, was also used.

The growth regulators were directly sprayed at $100 \mathrm{~L} \mathrm{ha}^{-1}$, using a manual-spray-type backpack with a constant pressure provided by a $\mathrm{CO}_{2}$-pressure source, and a conical nozzle type(TX-VS2). Solutions contained

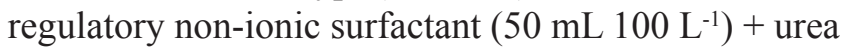
(1.0 \%), for best PGR adhesion and absorption.

The experimental area was irrigated, using a fixed-sprinkler conventional system, providing a flow rate of $3.3 \mathrm{~mm} \mathrm{~h}^{-1}$. Three crop coefficients (Kc) were used for water management. These $\mathrm{Kc}_{\mathrm{s}}$ were divided into four periods between emergence and harvest. For the vegetative phase, a $0.4 \mathrm{Kc}$ value was used; for the reproductive phase, a $0.7 \mathrm{Kc}$ value was used in the beginning, and a $1.0 \mathrm{Kc}$ value for the end of this phenological phase. For the mature phase, we used a $1.0 \mathrm{Kc}$ value for the beginning and a $0.7 \mathrm{Kc}$ value for the end of the mature phase, as suggested by Rodrigues et al. (2004).

Weeds, insects, and diseases were controlled to avoid yield loss. Nitrogen top-dressings (as urea) were applied at 30 and 60 days after emergence, at doses of $40+40 \mathrm{~kg} \mathrm{ha}^{-1} \mathrm{~N}$.

Leaf gas exchange parameters, such as the $\mathrm{CO}_{2}$ assimilation(A) and transpiration (E) rates, and stomatal conductance (gs) were measured throughout the cycle of the Primavera upland rice cultivar. A closed-gas portable photosynthesis system LI-6200 (LI-COR, Lincoln, NE USA) with a 0.25 L leaf chamber was used. $\mathrm{CO}_{2}$ concentration in the leaf cuvette averaged

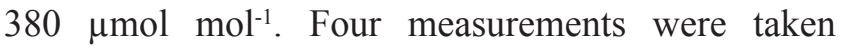
on unclouded days, under natural fluctuation of the photosynthetic photon flux density (PPFD), which oscillated between 700 and $1400 \mu \mathrm{mol} \mathrm{m} \mathrm{m}^{-2} \mathrm{~s}^{-1}$. Within the leaf cuvette, air temperature varied between 30.9 and $31.9^{\circ} \mathrm{C}$, and air humidity between 60.7 and $62.6 \%$.
Because the evaluation of gas exchange performance is best assessed during the highest PPFD and before air temperature reaches limiting values for $C_{3}$ photosynthetic-mechanism plants (Souza et al., 2008; Habermann et al., 2008, 2011), plants were assessed between 9:00 and 11:00 h. Two flag leaves per plant were measured from booting to milk phase, randomly chosen in each plot. Additionally, the water-use efficiency (A/E; WUE) was also computed, according to Habermann et al. (2008).

Manual harvest was done when about $90 \%$ of panicles had typical mature-color grains. Panicles were dried in the sun for two days and, then, subjected to mechanical threshing. The evaluations performed were: plant height from soil to tallest panicle, when grains were at the soft dough stage, by randomly selecting 20 plants in each plot; number of panicles per square meter, which was obtained by counting the number of panicles within $2.0 \mathrm{~m}$ plant row of two rows in the useful plot area; total number of spikelets per panicle, which was obtained by counting the number of spikelets in 20 panicles; spikelet fertility, determined as the percentage of grain-bearing spikelets. The 1,000-grain mass was evaluated by randomly collecting and weighing four samples of 1,000 grains from each plot $\left(130 \mathrm{~g} \mathrm{~kg}^{-1}\right.$ wet basis), and grain yield (unhulled grains) was determined by the weight of harvested grains from the useful plot area, correcting the moisture content to $13 \mathrm{~g} \mathrm{~kg}^{-1}$ and converting it to kilograms per hectare.

Mean values from leaf gas exchange parameters, number of panicles per square meter, number of spikelets per panicle, spikelet fertility, 1,000-grain weight, and grain yield were subjected to a two-way analysis of variance, and mean values were compared by the LSD's test, at $5 \%$ probability. Pearson's correlation analysis was conducted to investigate the relationship between upland rice yield and yield components, as well as between plant height and gas exchange parameters.

\section{Results and Discussion}

Plant growth regulators (PGR) and application time did not affect gas exchange rates of Primavera upland rice cultivar (Table 1). Neither the interaction between these factors had a significant effect on gas exchange rates. Our results contradict those obtained by Grossmann \& Retzlaff (1997) and Fagan et al. 
(2010), who applied kresoxim-methyl on wheat, and pyraclostrobin on soybean, respectively. These authors observed a significant increase in photosynthetic rates (A) in plants treated with those PGR. According to them, many PGR can directly favor A, although temporarily inhibiting plant respiration. Our results, however, agree with those by Neves et al. (2002), who did not observe differences in gas exchange rates measured in banana crop treated with PGR.

PGR applied at early tillering significantly reduced plant height, in comparison with the control treatment (Table 2). Application of TXE caused the lowest plant height $(82 \mathrm{~cm})$, followed by PBZ $(105 \mathrm{~cm})$ and MC $(112 \mathrm{~cm})$. However, when applied at the panicle differentiation, $\mathrm{MC}$ induced plant height $(128 \mathrm{~cm})$, which was even higher than that of the control treatment. Notwithstanding, TXE and PBZ caused significant reductions in plant height (Table 2).

The expressive reduction in rice plant height (Table 2), obtained in most of the cases, were expected because PGR inhibit biosynthesis of gibberellins, preventing the formation of stem elongation promoters (Sun, 2004). However, the absence of response of gas exchange rates to the PGR is a relevant finding, since it indicates that these products can be used on rice crop, reducing plant height and preventing plant lodging, without harming the productivity. There is a big concern on whether the use of PGR can impair

Table 1. Analysis of variance and average values of net $\mathrm{CO}_{2}$ assimilation rate $\left(\mathrm{A}, \mu \mathrm{mol} \mathrm{m} \mathrm{m}^{-2} \mathrm{~s}^{-1}\right)$, transpiration $(\mathrm{E}$, mol m $\mathrm{m}^{-2} \mathrm{~s}^{-1}$ ), stomatal conductance $\left(\mathrm{gs}, \mathrm{mmol} \mathrm{m} \mathrm{m}^{-2} \mathrm{~s}^{-1}\right.$ ), and water use efficiency (WUE, $\mu \mathrm{mol} \mathrm{m} \mathrm{m}^{-2} \mathrm{~s}^{-1}$ per mol m $\mathrm{m}^{-2} \mathrm{~s}^{-1}$ ) in upland rice, as affected by the application of plant regulators at two growth stages: early tillering and panicle primordium differentiation stages.

\begin{tabular}{lcccc}
\hline Treatment & A & E & gs & WUE \\
\hline \multicolumn{5}{c}{ F values } \\
Regulator (R) & $0.590^{\text {ns }}$ & $0.218^{\text {ns }}$ & $1.474^{\text {ns }}$ & $0.582^{\text {ns }}$ \\
Application time (T) & $0.727^{\text {ns }}$ & $0.753^{\text {ns }}$ & $0.824^{\text {ns }}$ & $0.580^{\text {ns }}$ \\
R x T & $1.439^{\text {ns }}$ & $0.590^{\text {ns }}$ & $0.280^{\text {ns }}$ & $1.156^{\text {ns }}$ \\
\hline CV (\%) & 4.36 & 5.72 & 5.78 \\
\hline \multicolumn{5}{c}{ Plant regulator } \\
Control & 26.28 & 0.0103 & 0.906 \\
Mepiquat chloride & 25.75 & 0.0103 & 0.867 & 2,597 \\
Paclobutrazol & 26.45 & 0.0105 & 0.959 & 2,547 \\
Trinexapac-ethyl & 25.99 & 0.0102 & 0.892 & 2,610 \\
\hline & \multicolumn{5}{c}{ Application Time } \\
Early tillering & 22.53 & 0.0102 & 1.01 & 2,917 \\
Panicle differentiation & 29.70 & 0.0104 & 0.80 & 2,268 \\
\hline
\end{tabular}

plant development, and our results indicated that this does not occur in upland rice cultivation.

Probably, at higher doses, greater reductions in photosynthesis rates would have been noted, as Reddy et al. (1996) observed them in cotton plants treated with high dosages of MC.

Some authors have obtained increased rates of gas exchange after PGR application (Grossmann \& Retzlaff, 1997; Fagan et al., 2010); however, the product used by these researchers was different from the ones tested in the present study. Nevertheless, hormonal imbalance seems to be less related to carbon gain than with plant height.

Table 2. Plant height, yield components, and productivity of upland rice as affected by plant regulators (mepiquat chloride - MC, paclobutrazol - PBZ, trinexapac-ethil - TXE) and application time ${ }^{(1)}$.

\begin{tabular}{|c|c|c|c|c|c|}
\hline \multirow{2}{*}{$\begin{array}{l}\text { Application } \\
\text { time }\end{array}$} & \multirow[t]{2}{*}{ Control } & \multicolumn{3}{|c|}{ Plant regulators } & \multirow[t]{2}{*}{ Averag } \\
\hline & & $\mathrm{MC}$ & $\mathrm{PBZ}$ & TXE & \\
\hline & \multicolumn{5}{|c|}{ Plant height $(\mathrm{cm})$} \\
\hline Early tillering & $115 \mathrm{aA}$ & $112 \mathrm{bB}$ & $105 \mathrm{aC}$ & $82 \mathrm{aD}$ & 103 \\
\hline Panicle differentiation & $117 \mathrm{aB}$ & $128 \mathrm{aA}$ & $73 \mathrm{bC}$ & $65 \mathrm{bD}$ & 96 \\
\hline Mean & 116 & 120 & 89 & 73 & \\
\hline \multirow[t]{2}{*}{ CV $(\%)$} & \multicolumn{4}{|c|}{8.12} & \\
\hline & \multicolumn{5}{|c|}{ Number of panicles per $\mathrm{m}^{2}$} \\
\hline Early tillering & $207 \mathrm{aA}$ & $181 \mathrm{bB}$ & $189 \mathrm{aB}$ & $207 \mathrm{aA}$ & 196 \\
\hline Panicle differentiation & $199 \mathrm{aAB}$ & $213 \mathrm{aA}$ & $171 \mathrm{bC}$ & $191 \mathrm{aB}$ & 194 \\
\hline Mean & 203 & 197 & 180 & 199 & \\
\hline \multirow[t]{2}{*}{$\mathrm{CV}(\%)$} & \multicolumn{4}{|c|}{6.53} & \\
\hline & \multicolumn{5}{|c|}{ Number of spikelet per panicle } \\
\hline Early tillering & $105 \mathrm{aB}$ & $113 \mathrm{aA}$ & $105 \mathrm{aB}$ & $79 \mathrm{bC}$ & 100 \\
\hline Panicle differentiation & $109 \mathrm{aA}$ & $109 \mathrm{aA}$ & $98 \mathrm{bB}$ & $113 \mathrm{aA}$ & 107 \\
\hline Mean & 107 & 111 & 101 & 96 & \\
\hline \multirow[t]{2}{*}{ CV $(\%)$} & \multicolumn{4}{|c|}{4.82} & \\
\hline & \multicolumn{5}{|c|}{ Spikelet fertility (\%) } \\
\hline Early tillering & $78 \mathrm{aA}$ & $77 \mathrm{aA}$ & $75 \mathrm{aA}$ & $78 \mathrm{aA}$ & 77 \\
\hline Panicle differentiation & $74 \mathrm{aA}$ & $79 \mathrm{aA}$ & $65 \mathrm{bB}$ & $30 \mathrm{bC}$ & 61 \\
\hline Mean & 76 & 78 & 70 & 54 & \\
\hline \multirow[t]{2}{*}{ CV $(\%)$} & \multicolumn{4}{|c|}{5.33} & \\
\hline & \multicolumn{5}{|c|}{ Weight of 1,000 grains $(\mathrm{g})$} \\
\hline Early tillering & $30.0 \mathrm{aA}$ & $31.1 \mathrm{aA}$ & $30.2 \mathrm{aA}$ & $27.0 \mathrm{aB}$ & 29.6 \\
\hline Panicle differentiation & $30.3 \mathrm{aAB}$ & $32.3 \mathrm{aA}$ & $28.9 \mathrm{aB}$ & $26.0 \mathrm{aC}$ & 29.4 \\
\hline Mean & 30.1 & 31.7 & 29.6 & 26.5 & \\
\hline \multirow[t]{2}{*}{ CV (\%) } & \multicolumn{4}{|c|}{7.31} & \\
\hline & \multicolumn{5}{|c|}{ Grain yield $\left(\mathrm{kg} \mathrm{ha}^{-1}\right)$} \\
\hline Early tillering & $4,678 \mathrm{aA}$ & $4,502 \mathrm{bA}$ & $4,183 \mathrm{aA}$ & $3,206 \mathrm{aB}$ & 4,142 \\
\hline Panicle differentiation & $4,564 \mathrm{aB}$ & $5,393 \mathrm{aA}$ & $2,896 \mathrm{bC}$ & $1,524 \mathrm{bD}$ & 3,594 \\
\hline Mean & 4,620 & 4,947 & 3,539 & 2,365 & \\
\hline $\mathrm{CV}(\%)$ & \multicolumn{4}{|c|}{12.23} & \\
\hline
\end{tabular}

${ }^{(1)}$ Means followed by equal letters, lowercase in columns and uppercase in rows, do not differ by LSD test, at $5 \%$ probability. 
The number of panicles was also affected by PGR, application timing and interaction between factors (Table 2). At the early tillering, application of MC and PBZ reduced the amount of panicles compared to the other treatments. However, when the application was done at panicle differentiation phase, MC provided the highest amount of panicles, which was significantly higher than PBZ and TXE. Moreover, plant height reduction, observed with TXE at this stage, did not occur at early tillering. Therefore, the effects of these PGR are closely related to application timing.

PGR did not affect grain yield when application was done at early tillering, except for TXE, which resulted in a significantly lower yield than the other treatments (Table 2). This result is consistent with the ones observed for yield components, specially grain weight and number of spikelets per panicle. However, when the application was done at panicle differentiation, $\mathrm{MC}$ provided the highest yield.

For application-timing effects, MC was observed as better used at panicle differentiation (Table 2), while PBZ and TXE caused great reduction of yield, when the application was done at this stage. However, despite the good results with the use of $\mathrm{MC}$ at panicle differentiation, this treatment provided the highest plant height. Therefore, further studies are needed, in order to evaluate the effects of other PGR rates, and to find possible combinations which could prevent high-plant heights and provide good yields.

As to $\mathrm{MC}$, it was evident that it acted as a growth stimulator, indicating a new line of research to be developed with modern-type cultivars, where this regulator could increase grain yield without causing significant effect in lodging, since these plants have low heights. Nobrega et al. (1999) and Tavares \& Lucchesi (1999) reported that the use of MC increased crop yields of cotton and potato. Therefore, even though the physiological effect of mepiquat chloride in determining higher yields is not yet explained, our results were not entirely unexpected.

There was a very close relationship between yield components and grain yield; and between these and plant height (Table 3). Therefore, it was evident that the reduction of plant height, caused by plant regulators, mainly by TXE (Table 2), also resulted in negative consequences for yield components, with direct consequence on grain yield.
Table 3. Pearson correlation coefficient for gas exchange rates - net $\mathrm{CO}_{2}$ assimilation rate $(\mathrm{A})$, stomatal conductance (gs), transpiration (E), water-use efficiency (WUE) -, plant height $(\mathrm{PH})$, and yield components of upland rice - number of panicles per square meter (PAN), number of spikelets per panicle (SPK), spikelet fertility (Fert), weight of 1,000 grains $(\mathrm{W} 1,000)$ and grain yield $(\mathrm{GY})$.

\begin{tabular}{|c|c|c|c|c|c|c|c|c|c|}
\hline & gs & $\mathrm{E}$ & WUE & PH & PAN & Spk & Fert & $\mathrm{W} 1,000$ & GY \\
\hline$\overline{\mathrm{A}}$ & $0.72 * *$ & ns & $0.79 * *$ & ns & ns & $-0.35^{*}$ & $0.53^{* *}$ & ns & ns \\
\hline gs & & $0.47^{* *}$ & ns & ns & ns & ns & $0.40^{*}$ & ns & ns \\
\hline E & & & $-0.61 * *$ & ns & ns & ns & ns & ns & ns \\
\hline WUE & & & & ns & ns & ns & $0.41^{*}$ & ns & ns \\
\hline PH & & & & & $0.35 *$ & $0.34^{*}$ & $0.70^{* *}$ & $0.65^{* *}$ & $0.91 * *$ \\
\hline PAN & & & & & & ns & ns & ns & $0.36^{*}$ \\
\hline Spk & & & & & & & ns & $0.41^{*}$ & $\mathrm{~ns}$ \\
\hline Fert & & & & & & & & $0.51^{* *}$ & $0.80^{* *}$ \\
\hline W 1,000 & & & & & & & & & $0.80^{* *}$ \\
\hline
\end{tabular}

ns Nonsignificant. **, *Significant at 1 and $5 \%$ probability, respectively.

Although PGR did not affect gas exchange, their effects on plant height, yield components, and grain yield suggest that they can be acting in other physiological process. In addition to that, a physiological explanation for the growth promotion by $\mathrm{MC}$ is still lacking. Therefore, researches must be planned, in order to further elucidate the physiological effects of PGR on plants.

\section{Conclusions}

1. Leaf gas exchange rates of upland rice under sprinkler irrigation conditions are influenced neither by plant growth regulators nor by their application time.

2. Application of trinexapac-ethyl reduces rice plant height, but also has a drastic negative effect on yield components and productivity, either at early tillering or at the panicle primordium differentiation.

3. Paclobutrazol or mepiquat chloride applied during the tillering stage reduces plant height without affecting upland rice yield.

4. When applied at the panicle primordium differentiation stage, mepiquat chloride acts as a growth stimulator, increasing plant height, panicle number and grain yield.

\section{Acknowledgments}

To the Fundação de Amparo à Pesquisa do Estado de São Paulo, for the financial support; to Conselho Nacional de Desenvolvimento Científico e Tecnológico for productivity grants.

Pesq. agropec. bras., Brasília, v.47, n.10, p.1455-1461, out. 2012 


\section{References}

ARF, O.; NASCIMENTO, V. do; RODRIGUES, R.A.F.;ALVAREZ, R. de C.F.; GITTI, D. de C.; SÁ, M.E. de. Uso de etil-trinexapac em cultivares de arroz de terras altas. Pesquisa Agropecuária Tropical, v.42, p.150-158, 2012.

ARF, O.; RODRIGUES, R.A.F.; SÁ, M.E. de; CRUSCIOL, C.A.C. Resposta de cultivares de arroz de sequeiro ao preparo do solo e à irrigação por aspersão. Pesquisa Agropecuária Brasileira, v.36, p.871-879, 2001.

BUZETTI, S.; BAZANINI, G.C.; FREITAS, J.G. de;ANDREOTTI, M.; ARF, O.; SÁ, M.E. de; MEIRA, F. de A. Resposta de cultivares de arroz a doses de nitrogênio e do regulador de crescimento cloreto de clormequat. Pesquisa Agropecuária Brasileira, v.41, p.1731-1737, 2006.

CRUSCIOL, C.A.C.; ARF, O.; SORATTO, R.P.; MATEUS, G.P. Grain quality of upland rice cultivars in response to cropping systems in the Brazilian tropical savanna. Scientia Agricola, v.65, p.468-473, 2008.

CRUSCIOL, C.A.C.; TOLEDO, M.Z.; ARF, O.; CAVARIANI, C. Water supplied by sprinkler irrigation system for upland rice seed production. Bioscience Journal, v.28, p.34-42, 2012.

ESPINDULA, M.C.; ROCHA, V.S.; SOUZA, L.T. de; SOUZA, M.A.; CAMPANHARO, M.; GROSSI, J.A.S. Rates of nitrogen and growth retardant trinexapac-ethyl on wheat. Ciência Rural, v.41, p.2045-2052, 2011.

FAGAN, E.B.; DOURADO NETO, D.; VIVIAN, R.; FRANCO, R.B.; YEDA, M.P.; MASSIGNAM, L.F.; OLIVEIRA, R.F. de; MARTINS, K.V. Efeito da aplicação de piraclostrobina na taxa fotossintética, respiração, atividade da enzima nitrato redutase e produtividade de grãos de soja. Bragantia, v.69, p.771-777, 2010.

FALQUETO, A.R.; CASSOL, D.; MAGALHÃES JÚNIOR, A.M.; OLIVEIRA, A.C. de; BACARIN, M.A. Crescimento e partição de assimilados em cultivares de arroz diferindo no potencial de produtividade de grãos. Bragantia, v.68, p.453-461, 2009.

GROSSMANN, K.; RETZLAFF, G. Bioregulatory effects of the fungicidal strobilurin kresoxim methyl in wheat (Triticum aestivum L.). Pesticide Science, v.50, p.11-20, 1997.

GUIMARÃES, C.M.; STONE, L.F.; OLIVEIRA, J.P.; RANGEL, P.H.N.; RODRIGUES, C.A.P. Sistema radicular do arroz de terras altas sob deficiência hídrica. Pesquisa Agropecuária Tropical, v.41, p.126-134, 2011.

HABERMANN, G.; ELLSWORTH, P.F.V.; CAZOTO, J.L.; FEISTLER, A.M.; SILVA, L.; DONATTI, D.A.; MACHADO, S.R. Leaf paraheliotropism in Styrax camporum confers increased light use efficiency and advantageous photosynthetic responses rather than photoprotection. Environmental and Experimental Botany, v.71, p.10-17, 2011.

HABERMANN, G.; MACHADO, S.R.; GUIMARÃES, V.F.; RODRIGUES, J.D. Leaf heliotropism in Styrax camporum Pohl from the Brazilian Cerrado - distinct gas exchange and leaf structure, but similar leaf temperature and water relations. Brazilian Journal of Plant Physiology, v.20, p.71-83, 2008.
KUMAR, V.; LADHA, J.K. Direct seeding of rice: recent developments and future research needs. Advances in Agronomy, v.111, p.297-396, 2011.

LEE, T.D.; REICH, P.B.; BOLSTAD, P.V. Acclimation of leaf respiration to temperature is rapid and related to specific leaf area, soluble sugars and leaf nitrogen across three temperate deciduous tree species. Functional Ecology, v.19, p.640-647, 2005.

LEITE, G.H.P.; CRUSCIOL, C.A.C.; SILVA, M. de A.; LIMA, G.P.P. Atividade das enzimas invertases e acúmulo de sacarose em cana-de-açúcar sob efeito do nitrato de potássio, etefon e etil-trinexapac. Ciência e Agrotecnologia, v.35, p.649-656, 2011.

NASCIMENTO, V. do; ARF, O.; SILVA, M.G. da; BINOTTI, F.F. da S.; RODRIGUES, R.A.F.; ALVAREZ, R. de C.F. Uso do regulador de crescimento etil-trinexapac em arroz de terras altas. Bragantia, v.68, p.921-929, 2009.

NEVES, L.L.M.; SIQUEIRA, D.L. de; CECON, P.R.; MARTINEZ, C.A.; SALOMÃO, L.C.C. Crescimento, trocas gasosas e potencial osmótico da bananeira-'Prata', submetida a diferentes doses de sódio e cálcio em solução nutritiva. Revista Brasileira de Fruticultura, v.24, p.524-529, 2002.

NOBREGA, L.B.; VIEIRA, D.J.; BELTRAO, N.E.M.; AZEVEDO, D.M.P. Efeito do regulador de crescimento cloreto de mepiquat na cultura do algodoeiro herbáceo no sertão paraibano. Revista Brasileira de Oleaginosa e Fibrosas, v.3, p.89-92, 1999.

NTANOS, D.A.; KOUTROUBAS, S.D. Dry matter and N accumulation and translocation for Indica and Japonica rice under Mediterranean conditions. Field Crops Research, v.74, p.93-101, 2002.

RAIJ, B. van; ANDRADE, J.C. de; CANTARELLA, H.; QUAGGIO, J.A. (Ed.). Análise química para avaliação da fertilidade de solos tropicais. Campinas: Instituto Agronômico de Campinas, 2001. 284p.

RAIJ, B. van; CANTARELA, H.; QUAGGIO, J.A.; FURLANI, A.M.C. Recomendações de adubação e calagem para o Estado de São Paulo. 2.ed. Campinas: Instituto Agronômico de Campinas, 1996. 285p. (IAC. Boletim técnico, 100).

REDDY, A.R.; REDDY, K.R.; HODGES, H.F. Mepiquat choride (PIX)-induced changes in photosynthesis and growth of cotton. Plant Growth Regulation, v.20, p.179-83, 1996.

RODRIGUES, R.A.F.; SORATTO, R.P.; ARF, O. Manejo de água em arroz de terras altas no sistema de plantio direto, usando o tanque classe A. Engenharia Agrícola, v.24, p.546-556, 2004.

SANTOS, A.B. dos; STONE, L.F.; VIEIRA, N.R. de A. A cultura do arroz no Brasil. 2.ed. Santo Antônio de Goiás: Embrapa Arroz e Feijão, 2006. 1000p.

SOUZA, G.M.; RIBEIRO, R.V.; SATO, A.M.; OLIVEIRA, M.S. Diurnal and seasonal carbon balance of four tropical tree species differing in successional status. Brazilian Journal of Biology, v.68, p.781-793, 2008.

SUN, T.-P. Gibberellin signal transduction in stem elongation and leaf growth. In: DAVIS, P.J. (Ed.). Plant hormones: biosynthesis, 
signal transduction, action! Dordrecht: Kluwer Academic, 2004. p.304-320.

TAVARES, S.; LUCCHESI, A.A. Reguladores vegetais na batata cv. Monalisa, após a tuberização. Scientia Agricola, v.56, p.975-980, 1999.

TUONG, T.P.; BOUMAN, B.A.M. Rice production in water-scarce environments. In: KIJNE, J.W.; BARKER, R.; MOLDEN, D. (Ed.).
Water productivity in agriculture: limits and opportunities for improvement. Wallingford: CABI International, 2003. p.53-67.

WRIGHT, I.J.; REICH, P.B.; ATKIN, O.K.; LUSK, C.H.; TJOELKER, M.G.; WESTOBY, M. Irradiance, temperature and rainfall influence leaf dark respiration in woody plants: evidence from comparisons across 20 sites. New Phytologist, v.169, p.309-319, 2005.

Received on March 17, 2012 and accepted on September 3, 2012 